\title{
Surface Roughness in Drilling of Electrically Conductive Polyamide
}

\author{
A. UYSAL* AND E. Altan
}

Yildiz Technical University, Department of Mechanical Engineering, 34349 Istanbul, Turkey

\begin{abstract}
In this study, drilling of unreinforced polyamide and carbon black reinforced electrically conductive polyamide was performed with drill tools having different drill point angle at different cutting speeds and feeds. The surface roughness of drilled holes was measured and the chip forms were investigated. The experimental studies were designed by utilizing Taguchi $\mathrm{L}_{9}$ orthogonal series in order to obtain optimum drilling parameters and analysis of variance (ANOVA) statistical method was used to specify the effects of the process parameters on the surface roughness.
\end{abstract}

DOI: 10.12693/APhysPolA.129.442

PACS/topics: 81.05.Qk

\section{Introduction}

Polymer materials provide many advantages such as corrosion resistance, light in weight, good strength to weight ratio, cost effectiveness etc. and they are used in many applications [1]. Additionally, polymer materials are needed in semiconductive applications in automotive and electronic industries [2-4]. For this reason, electrically conductive polymer composite materials were produced by adding carbon black, carbon fiber, graphene, metal oxides, and carbon nanotubes to the polymer materials [5-7]. Polymer products are generally manufactured by injection molding but some machining operations should be applied. Various studies were performed to investigate the effects of process parameters in drilling of polymer materials. Rubio et al. [8] investigated the drilling of glass whisker reinforced polyamide composite materials and examined the effects of feed, cutting speed, and drill point angle on the surface roughness. According to the results, the interaction between the feed, spindle speed, and drill point angle had significant effect on the surface roughness. Gaitonde et al. [9] studied the drilling of unreinforced polyamide and glass fiber reinforced polyamide materials and investigated the effects of cutting speed and feed on the surface roughness. Depending on the experimental results, lower surface roughness was measured for reinforced polyamide as compared to unreinforced polyamide. In literature, there is not much study on the machining of particle reinforced polymer composite materials. In this study, drilling of unreinforced polyamide and carbon black reinforced electrically conductive polyamide composite was investigated and the effects of cutting speed, feed, and drill point angle on the surface roughness and chip forms were specified. In addition, some statistical methods were utilized to determine the optimum drilling conditions for minimum surface roughness and the contribution of process parameters.

\section{Materials and equipments}

Unreinforced polyamide (PA) and carbon black reinforced electrically conductive polyamide (CBR-PA) were selected as workpiece materials. Firstly, polyamide granules were dried at $60^{\circ} \mathrm{C}$ for $2 \mathrm{~h}$, polymer samples were produced in dimensions of $150 \times 150 \times 10 \mathrm{~mm}^{3}$ by injection molding at $60^{\circ} \mathrm{C}$ mold temperature and $70 \mathrm{MPa}$ injection pressure. Drilling experiments were conducted with uncoated high speed steel (HSS) twist drill tools by using First MCV-300 CNC machining center. The drill tool diameter was $8 \mathrm{~mm}$. Surface roughness $\left(R_{\mathrm{a}}\right)$ of drilled holes was measured by Time TR200 surface roughness tester. Five measurements were performed for all drilled holes and arithmetic means of the measurements were determined. The photographs of chip forms were taken by SOIF XLB45-B3 digital stereo microscope.

\section{Methodology}

The Taguchi method was utilized to determine the optimum drilling parameters for minimum surface roughness and to specify the most effective parameter on the surface roughness. Drill point angle, feed, and cutting speed were selected as key factors as seen in Table I. In this study, the $\mathrm{L}_{9}$ orthogonal array $(\mathrm{OA})$ was chosen. The signal-to-noise $(\mathrm{S} / \mathrm{N})$ ratios were determined and the "smaller is better" quality characteristic was selected. In addition, analysis of variance (ANOVA) was used to define the significance and contribution of all drilling parameters. 
TABLE I

Drilling parameters and levels.

\begin{tabular}{c|c|c|c}
\hline \hline Factors & Level 1 & Level 2 & Level 3 \\
\hline Drill point angle $(\alpha), A\left[^{\circ}\right]$ & 80 & 120 & $80-120$ \\
Feed $(f), B[\mathrm{~mm} / \mathrm{rev}]$ & 0.1 & 0.2 & 0.3 \\
Cutting speed $(V), C[\mathrm{~m} / \mathrm{min}]$ & 40 & 80 & 120
\end{tabular}

\section{Results and discussion}

\subsection{Effects of drilling parameters on the surface roughness and chip form}

According to Fig. 1a and b, high cutting speed caused a decrease in the surface roughness for unreinforced and reinforced polyamides owing to the fact that the cutting of polymer materials was performed easily as reported

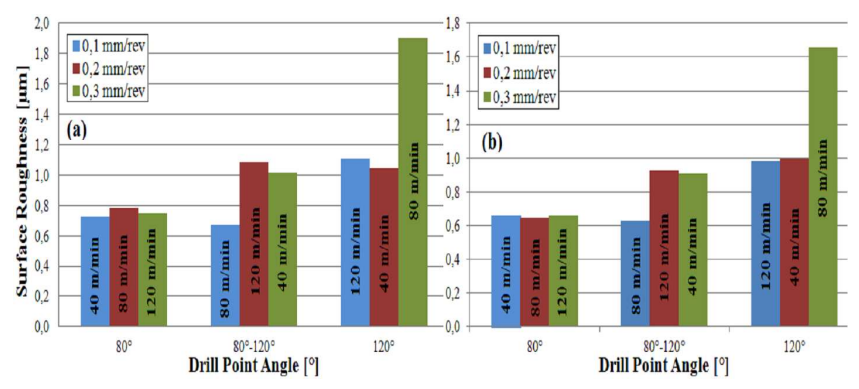

Fig. 1. Surface roughness results: (a) unreinforced PA, (b) carbon black reinforced PA.

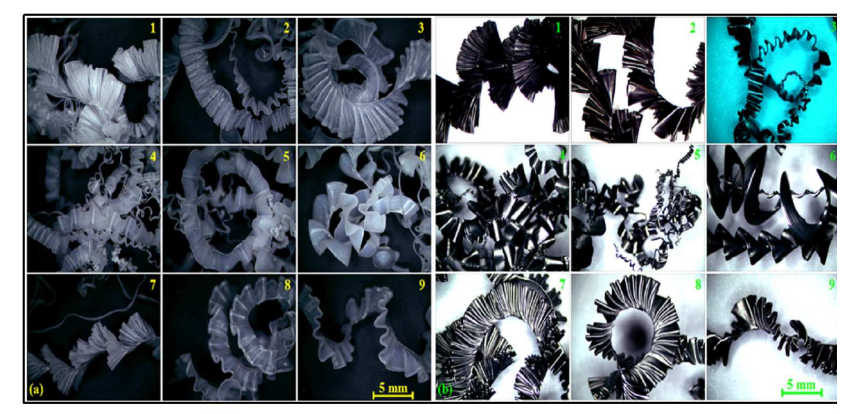

Fig. 2. Chip forms: (a) unreinforced PA, (b) carbon black reinforced PA.

in the study of Gaitonde et al. [9]. The surface roughness increased with increase of the feed because of occurring plastic deformation at high feed. In addition, Uysal et al. [10] reported that the small drill point angle reduced the friction and so it provided lower surface roughness. The double-angled $\left(80^{\circ}-120^{\circ}\right)$ drill tool gave better results than the drill tool with $120^{\circ}$ point angle [10] but the drill tool with $80^{\circ}$ point angle allowed lower surface roughness. As seen in Fig. 2a and b, the chip forms were more deformed and undesired chips were formed as increasing the cutting speed and decreasing the feed. Because, more heat was generated at high cutting speed and low feed due to the friction and the generated heat could not be transmitted to drill tool and it was accumulated at a thin surface layer. Therefore, more deformed chips affected by heat occurred. Additionally, small drill point angle provided more regular chip forms due to facilitate the cutting. In the polymer materials, the carbon black reinforcement increases the thermal conductivity as it increases the electrical conductivity. For this reason, the generated heat is well conducted to the drill tool in the drilling of carbon black reinforced PA. Besides, the polymer materials become tougher by adding the carbon black. For these reasons, lower surface roughness and more regular chip forms were observed.

\subsection{Analysis of Taguchi and ANOVA results}

The measured surface roughness and the corresponding $\mathrm{S} / \mathrm{N}$ ratios are presented in Table II. Additionally, the response table of $\mathrm{S} / \mathrm{N}$ ratios and $\mathrm{S} / \mathrm{N}$ ratio response plots are given in Table III and Fig. 3, respectively. Figure 3a presents $\mathrm{S} / \mathrm{N}$ ratio response plot for unreinforced $\mathrm{PA}$ and Fig. 3b presents $\mathrm{S} / \mathrm{N}$ ratio plot for carbon black reinforced PA. Depending on the Taguchi results, the optimum drilling parameters were determined as A1B1C3 for both polymer materials. This data set is not included in the conducted experiments. For this reason, confirmation experiments were performed at the drill point angle of $80^{\circ}$, the feed of $0.1 \mathrm{~mm} / \mathrm{rev}$, and the cutting speed of $120 \mathrm{~m} / \mathrm{min}$. After conducting the confirmation tests, surface roughness values were measured as $0.53 \mu \mathrm{m}$ for unreinforced PA and as $0.40 \mu \mathrm{m}$ for carbon black reinforced PA and so the minimum values were obtained. Besides, high delta values seen in Table III give the most effective drilling parameter on the surface roughness. It was drill point angle with the delta of 4.7723 for unreinforced PA and with the delta of 5.08041 for carbon black reinforced PA.

TABLE II

$\mathrm{S} / \mathrm{N}$ ratios and measured surface roughness.

\begin{tabular}{c|c|c|c|c|c|c|c}
\hline \hline $\begin{array}{c}\text { Exp. } \\
\text { No. }\end{array}$ & $\begin{array}{c}\text { Drill } \\
\text { point } \\
\text { Angle, } \\
A\left[{ }^{\circ}\right]\end{array}$ & $\begin{array}{c}\text { Feed, } B \\
{[\mathrm{~mm} / \mathrm{rev}]}\end{array}$ & $\begin{array}{c}\text { Cutting } \\
\text { speed, } C \\
{[\mathrm{~m} / \mathrm{min}]}\end{array}$ & $\begin{array}{c}\text { Unreinforced PA } \\
\text { roughness } \\
{[\mu \mathrm{m}]}\end{array}$ & $\begin{array}{c}\mathrm{S} / \mathrm{N} \\
{[\mathrm{dB}]}\end{array}$ & $\begin{array}{c}\text { Surface } \\
\text { roughness } \\
{[\mu \mathrm{m}]}\end{array}$ & $\begin{array}{c}\mathrm{S} / \mathrm{N} \\
{[\mathrm{dB}]}\end{array}$ \\
\hline 1 & 80 & 0.1 & 40 & 0.72 & 2.79723 & 0.66 & 3.61175 \\
2 & 80 & 0.2 & 80 & 0.78 & 2.12476 & 0.65 & 3.78863 \\
3 & 80 & 0.3 & 120 & 0.74 & 2.57146 & 0.66 & 3.60649 \\
4 & 120 & 0.1 & 80 & 1.10 & -0.85676 & 0.99 & 0.12246 \\
5 & 120 & 0.2 & 120 & 1.05 & -0.38233 & 1.00 & 0.01652 \\
6 & 120 & 0.3 & 40 & 1.90 & -5.58421 & 1.65 & -4.37334 \\
7 & $80-120$ & 0.1 & 120 & 0.67 & 3.43970 & 0.63 & 4.06574 \\
8 & $80-120$ & 0.2 & 40 & 1.08 & -0.69257 & 0.93 & 0.64904 \\
9 & $80-120$ & 0.3 & 80 & 1.02 & -0.16348 & 0.91 & 0.81345
\end{tabular}

In the drilling of both PA, the drill point angle was the most significant parameter according to the Taguchi results. As seen in Table IV, the highest percentage of contribution was determined for the drill point angle. In addition, the cutting speed and the feed were obtained as effective parameters, respectively. 
TABLE III

The response table of $\mathrm{S} / \mathrm{N}$ ratios.

\begin{tabular}{c|c|c|c|c|c|c}
\hline \hline & \multicolumn{3}{|c|}{ Unreinforced PA } & \multicolumn{3}{c}{ CBR-PA } \\
\cline { 2 - 7 } & $\begin{array}{c}\text { Drill } \\
\text { point } \\
\end{array}$ & $\begin{array}{c}\text { Feed, } B \\
\text { angle, } \\
{[\mathrm{mm} / \mathrm{rev}]}\end{array}$ & $\begin{array}{c}\text { Cutting } \\
\text { speed, } C \\
{[\mathrm{~m} / \mathrm{min}]}\end{array}$ & $\begin{array}{c}\text { Drill } \\
\text { point } \\
\text { angle, } \\
A\left[^{\circ}\right]\end{array}$ & $\begin{array}{c}\text { Feed, } B \\
{[\mathrm{~mm} / \mathrm{rev}]}\end{array}$ & $\begin{array}{c}\text { Cutting } \\
\text { speed, } C \\
{[\mathrm{~m} / \mathrm{min}]}\end{array}$ \\
\hline lev. 1 & 2.4978 & 1.7934 & -1.1598 & 3.66896 & 2.59998 & -0.03751 \\
lev. 2 & -2.2744 & 0.3500 & 0.3682 & -1.41145 & 1.48473 & 1.57485 \\
lev. 3 & 0.8612 & -1.0587 & 1.8763 & 1.84274 & 0.01553 & 2.56292 \\
$\delta$ & 4.7723 & 2.8521 & 3.0361 & 5.08041 & 2.58445 & 2.60043
\end{tabular}

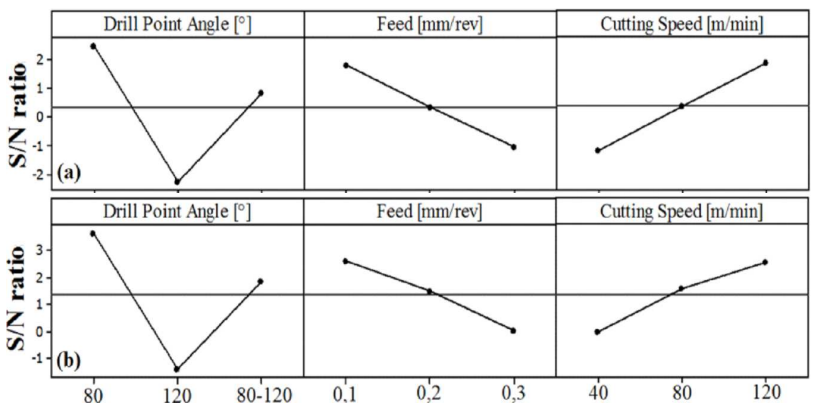

Fig. 3. S/N ratio response plots: (a) unreinforced PA, (b) carbon black reinforced PA.

TABLE IV

ANOVA results

\begin{tabular}{|c|c|c|c|c|c|}
\hline Parameter & \begin{tabular}{|c|} 
Sum \\
of \\
square
\end{tabular} & $\begin{array}{c}\text { Degree } \\
\text { of } \\
\text { freedom }\end{array}$ & $\begin{array}{c}\text { Mean } \\
\text { square }\end{array}$ & F-ratio & $\begin{array}{c}\text { Percentage } \\
\text { contribution } \\
{[\%]}\end{array}$ \\
\hline \multicolumn{6}{|c|}{ Unreinforced PA } \\
\hline drill point angle $\left[^{\circ}\right]$ & 0.57097 & 2 & 0.28549 & 9.75 & 50.59 \\
\hline feed $[\mathrm{mm} / \mathrm{rev}]$ & 0.23217 & 2 & 0.11608 & 3.96 & 20.58 \\
\hline cutting speed $[\mathrm{m} / \mathrm{min}]$ & 0.26675 & 2 & 0.13338 & 4.56 & 23.64 \\
\hline residual & 0.05856 & 2 & 0.02928 & & 5.19 \\
\hline total & 1.12846 & 8 & & & \\
\hline \multicolumn{6}{|c|}{ Carbon Black Reinforced PA } \\
\hline drill point angle $\left[^{\circ}\right.$ ] & 0.49134 & 2 & 0.24567 & 17.46 & 58.39 \\
\hline feed $[\mathrm{mm} / \mathrm{rev}]$ & 0.15835 & 2 & 0.07918 & 5.63 & 18.82 \\
\hline cutting speed $[\mathrm{m} / \mathrm{min}]$ & 0.16368 & 2 & 0.08184 & 5.82 & 19.45 \\
\hline residual & 0.02815 & 2 & 0.01407 & & 3.34 \\
\hline total & 0.84151 & 8 & & & \\
\hline
\end{tabular}

\section{Conclusion}

Surface roughness decreased with increase of the cutting speed and it increased with increase of the feed. Additionally, small drill point angle caused a decrease in the surface roughness. The double-angled $\left(80^{\circ}-120^{\circ}\right)$ drill tool had advantages but not as much as the drill tool with $80^{\circ}$ point angle. Irregular and more deformed chip forms occurred when the cutting speed increased and the feed decreased. However, more regular chips were formed in the drilling by the drill tool with $80^{\circ}$ point angle. Besides, surface roughness was lower and chip forms more regular in the drilling of carbon black reinforced PA than that obtained in the drilling of unreinforced PA. Depending on the Taguchi results, the optimal parameters for minimum surface roughness were the drill point angle of $80^{\circ}$, feed of $0.1 \mathrm{~mm} / \mathrm{rev}$, and cutting speed of $120 \mathrm{~m} / \mathrm{min}$. In addition, ANOVA results showed that the most effective parameter was the drill point angle for both polyamides.

\section{Acknowledgments}

This research has been supported by Ylldız Technical University Scientific Research Projects Coordination Department, project No. 2014-06-01-GEP01.

\section{References}

[1] M. Alauddin, I.A. Choudhury, M.A. El Baradie, M.S.J. Hashmi, J. Mater. Process. Tech. 54, 40 (1995).

[2] S.K.H. Gulrez, M.E.A. Mohsin, H. Shaikh, A. Anis, A.M. Pulose, M.K. Yadav, E.H.P. Qua, S.M. AlZahrani, Polym. Compos. 35, 900 (2014).

[3] O.S. Carneiro, J.A. Covas, R. Reis, B. Brule, J.J. Flat, J. Thermoplast. Compos. 25, 607 (2012).

[4] I. Kim, J. Vinyl. Addit. Techn. 13, 71 (2007).

[5] I. Krupa, V. Cecen, A. Boudenne, J. Prokeš, I. Novák, Mater. Des. 51, 620 (2013).

[6] A. Lonjon, I. Caffrey, D. Carponcin, E. Dantras, C. Lacabanne, J. Non-Cryst. Solids 376, 199 (2013).

[7] S. Araby, L. Zhang, H.C. Kuan, J.B. Dai, P. Majewski, J. Ma, Polymer 54, 3663 (2013).

[8] J.C. Rubio, T.H. Panzera, A.M. Abrao, P.E. Faira, J.P. Davim, J. Compos. Mater. 45, 1395 (2011).

[9] V.N. Gaitonde, S.R. Karnik, J.C. Rubio, A.M. Abrão, A.E. Correia, J.P. Davim, J. Compos. Mater. 46, 2659 (2012).

[10] A. Uysal, M. Altan, E. Altan, Int. J. Adv. Manuf. Tech. 58, 915 (2012). 